\section{Diagnostic accuracy and complications of frozen section examination of equivocal malignant testicular masses}

Axel Alberto Cayetano-Alcaraz, ${ }^{1}$ Mirha Halilovic, ${ }^{1}$ Natalia Olavarria-Sayavedra, ${ }_{1}^{1}$ Christian Aníbal Quiñones-Capistrán, ${ }^{1}$ Ricardo Arceo-Olaiz, ${ }^{2}$ Ricardo Alonso Castillejos-Molina ${ }^{1}$

\begin{abstract}
BACKGROUND: Most testicular lesions are detected at the early stage and up to $10-20 \%$ of them are benign. Frozen section examination (FSE) has proven to be reliable for evaluating testicular lesions. The diagnosis of benign histology can prevent unnecessary radical orchiectomy and its complications.
\end{abstract}

OBJECTIVE: To evaluate the diagnostic accuracy of FSE of equivocal malignant testicular masses (EMTMs), as well as the short and longterm complications associated with that procedure.

MATERIALS AND METHODS: A retrospective study was conducted between 2005 and 2015 at a tertiary care center on patients that underwent testicular exploration through FSE due to EMTM. Diagnostic accuracy measures were obtained, and the short and long-term complications were recorded. The study design was carried out following the STARD (Standards for Reporting of Diagnostic Accuracy) recommendations.

RESULTS: Twenty-three patients were included in the study. Median follow-up was 10 months (interquartile range: 60 ). A total of $73.9 \%$ of the lesions were benign and $26.1 \%$ were malignant. There were no diagnostic changes in relation to the FSE and definitive pathology reports. Diagnostic accuracy measures were 100\%. The degree of concordance between the FSE and definitive malignancy reports was statistically significant $(\kappa=1.0, p<0.05)$. As a result of the benign FSE report, 12 radical orchiectomies (70.6\%) were prevented. Three patients $(12.5 \%)$ had grade I complications. In the long term, 2 patients presented with testicular atrophy. No malignant formations were observed during follow-up in the patients that did not undergo radical orchiectomy as a result of the benign FSE report.

CONCLUSION: Testicular frozen section examination is a reliable technique in equivocal malignant lesion management and is associated with low-grade complications.

KEYWORDS: Frozen Sections; Diagnostic accuracy; Testicular neoplasms; Retrospective studies; Testis pathology
${ }^{1}$ Department of Urology, Instituto Nacional de Ciencias Médicas y Nutrición Salvador Zubirán, Ciudad de México.

${ }^{2}$ Hospital Ángeles Pedregal, Ciudad de México.

Received: January 2018

Accepted: March 2018

Correspondence

Ricardo Alonso Castillejos Molina

rcastillejos@hotmail.com

This article should be cited as

Cayetano-Alcaraz AA, Halilovic M, OlavarriaSayavedra N, Quiñones-Capistrán CA, Arceo-Olaiz R, Castillejos-Molina RA. Diagnostic accuracy and complications of frozen section examination of equivocal malignant testicular masses. Rev Mex Urol. 2018 marzo-abril;78(2):128-134.

DOI: https://doi.org/10.24245/revmexurol.v78i2.1913 
Rev Mex Urol. 2018 March-April;78(2):128-134.

\title{
Precisión diagnóstica y complicaciones de la biopsia por congelamiento de masas testiculares malignas equívocas.
}

\author{
Axel Alberto Cayetano-Alcaraz, ${ }^{1}$ Mirha Halilovic, ${ }^{1}$ Natalia Olavarria-Sayavedra, ${ }^{1}$ \\ Christian Aníbal Quiñones-Capistrán, ${ }^{1}$ Ricardo Arceo-Olaiz, ${ }^{2}$ Ricardo Alonso \\ Castillejos-Molina ${ }^{1}$
}

\begin{abstract}
Resumen
ANTECEDENTES: La mayor parte de las lesiones testiculares se detectan en etapa temprana. En 10 a 20\% de los casos pueden ser benignas. La biopsia por congelamiento ha demostrado ser confiable para evaluar lesiones testiculares. El diagnóstico de histología benigna puede evitar orquiectomías radicales innecesarias y sus complicaciones.
\end{abstract}

OBJETIVO: Evaluar la precisión diagnóstica de la biopsia por congelamiento de lesiones testiculares malignas equívocas, las complicaciones a corto y largo plazos asociadas con este procedimiento.

MATERIALES Y MÉTODOS: Estudio retrospectivo efectuado de 2005 a 2015 en un centro hospitalario terciario, en pacientes con exploración testicular con biopsia por congelamiento debido a lesiones testiculares malignas equívocas. Se obtuvieron medidas de precisión diagnóstica. Se registraron las complicaciones a corto y largo plazo. El diseño del estudio se realizó siguiendo las recomendaciones STARD (Standards for Reporting of Diagnostic Accuracy, por sus siglas en inglés).

RESULTADOS: Se incluyeron 23 pacientes, con una mediana de seguimiento de diez meses (rango intercuartil: 60). El 73.9 y $26.1 \%$ de las lesiones fueron benignas y malignas, respectivamente. No se observaron cambios en el diagnóstico entre el reporte de la biopsia por congelamiento y el reporte definitivo de patología. Las medidas de precisión diagnóstica tuvieron un valor de $100 \%$. El grado de concordancia entre la biopsia por congelamiento y el reporte definitivo de malignidad, fue estadísticamente significativo $(\kappa=1.0, p<0.05)$. Debido al reporte benigno de la biopsia por congelamiento, se evitaron 12 orquiectomías radicales. Tres pacientes (12.5\%) tuvieron complicaciones grado I. Se encontró atrofia testicular, a largo plazo, en 2 pacientes. En los pacientes que no se sometieron a orquiectomía radical por reporte benigno de biopsia por congelamiento, no se detectaron formaciones malignas durante el seguimiento.

CONCLUSIÓN: La biopsia testicular por congelamiento representa una técnica confiable en el tratamiento de lesiones malignas equívocas y se relaciona con complicaciones de bajo grado.

PALABRAS CLAVE: Biopsia por Congelamiento; Precisión diagnóstica; Neoplasias testiculares; Estudios retrospectivos; Patología testicular.

\section{INTRODUCTION}

Most testicular lesions are currently diagnosed at earlier clinical stages and the detection of incidental focal lesions has increased due to the widespread use of testicular ultrasound imaging. ${ }^{1}$ Benign pathology is found in up to $10-20 \%$ of testicular tumors ${ }^{2}$. Recent studies have shown 
that testicular frozen section examination (FSE) is a useful and reliable method for evaluating testicular lesions of uncertain origin. [3, 4]. The finding of benign pathology through FSE can prevent unnecessary radical orchiectomy and its associated complications. Despite the recent evidence, this procedure continues to be underperformed.

The aim of our study was to retrospectively review our experience in the performance of testicular FSE in lesions of uncertain origin and its diagnostic accuracy.

To evaluate the diagnostic accuracy of FSE in equivocal malignant testicular masses (EMTMs), as well as its associated short and long-term complications.

\section{MATERIALS AND METHODS}

\section{Study design}

A retrospective study was conducted within the time frame of 2005 to 2015 at the Instituto Nacional de Ciencias Médicas y Nutrición "Salvador Zubirán" in Mexico City. The study was approved by our institutional ethics committee, based on the Helsinki Declaration. The study design was carried out following the STARD (Standards for Reporting of Diagnostic Accuracy) recommendations [5].

\section{Participants}

Selection criteria: patients $\geq 18$ years of age that underwent FSE in EMTMs. EMTMs were defined as palpable or incidentally-identified testicular lesions, accompanied by systemic or genitourinary comorbidities that could suggest a benign etiology, with normal levels of serum tumor markers and no evidence of metastatic disease. Potential participant data were obtained from the surgery database of the Urology Department. The patients included in the study were those that had undergone testicular exploration with FSE within the time frame of 2005 and 2015. Paratesticular FSE was excluded from the analysis.

We collected the demographic variables, comorbidities, signs and symptoms, presence of preoperative testis atrophy, laterality, ultrasound characteristics (color Doppler enhancement, diameter, and echo-structure), serum tumor marker levels, short and long-term complications according to the Clavien-Dindo classification, and later malignant development in patients with a benign histology report.

\section{Diagnostic Method}

The index test was the FSE in EMTMs and the reference standard was the definitive histopathologic report or radical orchiectomy specimen analyzed at the Pathology Department.

The FSE and definitive histopathology reports were classified as benign lesions (infection, benign tumors, atrophy, inflammation and/or normal tissue) or malignant lesions (seminomatous germ-cell tumor, non-seminomatous germ-cell tumors, lymphoproliferative diseases, or other malignant neoplasia). The FSE result was available to the pathologist that provided the definitive histopathology result.

\section{Surgical technique}

Testicular exploration was performed through inguinal incision. The spermatic cord was clamped with a vessel loop and cold ischemia of the testis was performed. Once the tunica vaginalis was opened and the EMTM was exposed, incisional or excisional biopsy was carried out, according to tumor location and size. If malignancy was reported in the FSE, a radical orchiectomy was performed.

\section{FSE technique}

In the Pathology Department a fresh sample was received and then embedded in a compound for 
cryosectioning (Tissue-Tek ${ }^{\circledR}$ O.C.T.), to provide a matrix, freezing the tissue after its placement in the Cryostat microtome $\left(<-35^{\circ} \mathrm{C}\right)$. Once the sample was frozen, it was sectioned into slices of 3-4 micrometers and stained with hematoxylin and eosin for light microscopic analysis. A standard paraffin-embedded analysis was then performed, and all samples were stained with hematoxylin and eosin for the definitive diagnosis.

\section{Statistical analysis}

The descriptive analysis was reported through mean and standard deviation (SD). Medians were described through interquartile range or proportion, based on data type and distribution. The categorical variables were compared using the $X^{2}$ test or Fisher's exact test and parametric and nonparametric tests were used for the continuous variables.

Sensitivity, specificity, negative predictive value (NPV), and positive predictive value (PPV) were calculated to evaluate FSE accuracy, using the definitive histopathology report as the gold standard. We calculated the degree of concordance between malignant FSE reports and malignant definitive histopathology reports using Cohen's Kappa coefficient. Statistical significance was set at a $p<0.05$. All reported $p$ values were twosided. The statistical analyses were performed using the IBM SPSS Statistics version 22 program.

\section{RESULTS}

\section{Population characteristics}

Twenty-six patients underwent FSE, 3 of whom were excluded due to paratesticular lesion, leaving a total of 23 patients in the study. Mean patient age at disease presentation was 37 years (SD: 13) with a median follow-up period of 10 months (IQR: 60 months). The main comorbidities reported were diabetes mellitus in 4 patients
(17.3\%), HIV infection in $2(8.6 \%)$, systemic lupus erythematosus in $3(13 \%)$, systemic hypertension in $2(8.6 \%)$, and tuberculosis in $1(4.3 \%)$ patient. The clinical characteristics and ultrasound findings are described in Tables 1 and 2.

\section{Surgical treatment and complications}

For the FSE, 17 (73.9\%) excisional biopsies and $6(26.1 \%)$ incisional biopsies were performed.

Table 1. Clinical characteristics of patients with equivocal malignant testicular masses

\begin{tabular}{|l|c|c|c|c|}
\hline $\begin{array}{l}\text { Clinical } \\
\text { characteristics }\end{array}$ & Total & $\begin{array}{c}\text { Definitive } \\
\text { malignant }\end{array}$ & $\begin{array}{c}\text { Definitive } \\
\text { benign }\end{array}$ & $\boldsymbol{p}$ \\
\hline $\begin{array}{l}\text { Palpable mass } \\
-\mathrm{n}(\%)\end{array}$ & $\begin{array}{c}13 \\
(56)\end{array}$ & 4 & 9 & 0.6 \\
\hline Pain - n (\%) & $\begin{array}{c}10 \\
(43.5)\end{array}$ & 2 & 8 & 0.6 \\
\hline $\begin{array}{l}\text { Testicular atrophy } \\
-\mathrm{n}(\%)\end{array}$ & 5 & 2 & 3 & 1.0 \\
\hline $\begin{array}{l}\text { Fever - n (\%) } \\
(21.7)\end{array}$ & $2(8.6)$ & 0 & 2 & 1.0 \\
\hline $\begin{array}{l}\text { Weight loss } \\
-\mathrm{n}(\%)\end{array}$ & $\begin{array}{c}1 \\
(4.3)\end{array}$ & 0 & 1 & 1.0 \\
\hline Fatigue & 1 & 1 & 0 & 1.0 \\
\hline$-\mathrm{n}(\%)$ & $(4.3)$ & & & \\
\hline
\end{tabular}

Table 2. Ultrasound characteristics of equivocal malignant testicular masses

\begin{tabular}{|c|c|c|c|}
\hline $\begin{array}{l}\text { Ultrasound } \\
\text { characteristics }\end{array}$ & Total & $\begin{array}{l}\text { Definitive } \\
\text { malignant }\end{array}$ & $\begin{array}{c}\text { Definitive } \\
\text { benign }\end{array}$ \\
\hline \multicolumn{4}{|l|}{ Echo structure - n (\%) } \\
\hline Hypoechoic & 6 & 3 & 3 \\
\hline Normal & 3 & 1 & 2 \\
\hline Hyperechoic & 1 & 0 & 1 \\
\hline Anechoic & 1 & 0 & 1 \\
\hline Heterogeneous & 10 & 2 & 8 \\
\hline Not reported & 2 & - & - \\
\hline Diameter - mean $(\mathrm{SD})^{*}$ & $\begin{array}{c}2.3 \\
(2.04)\end{array}$ & $2.0(1.4)$ & $2.4(2.2)$ \\
\hline $\begin{array}{l}\text { Enhancement with } \\
\text { color Doppler } \mathrm{n}(\%)\end{array}$ & $\begin{array}{c}5 \\
(21.7)\end{array}$ & $1(4.3)$ & $4(17.3)$ \\
\hline
\end{tabular}

*Diameter not reported in 7 cases. 
Malignancy through FSE was reported in six cases $(26.1 \%)$, (Figure 1). The definitive histology reports are summarized in Table 3.

In total, 10 radical orchiectomies were performed (43.5\%). Of the 6 malignant FSE reports, 5 of those patients $(83 \%)$ underwent radical orchiectomy and 1 patient with lymphoma did not. In addition, 5 patients with a benign FSE report (29.4\%) underwent orchiectomy due to chronic orchitis associated with syphilis $(n=1)$, fibrosis and ischemia $(\mathrm{n}=2)$, extensive necrosis $(\mathrm{n}=$ 1 ), and an adenomatoid tumor with associated ischemia $(n=1)$. Radical orchiectomy was performed in those patients because of the greatly compromised testicular condition. A total of 12 radical orchiectomies (70.6\%) were prevented, as a result of the benign FSE report.

Table 3. Definitive histopathology reports of EMTM.

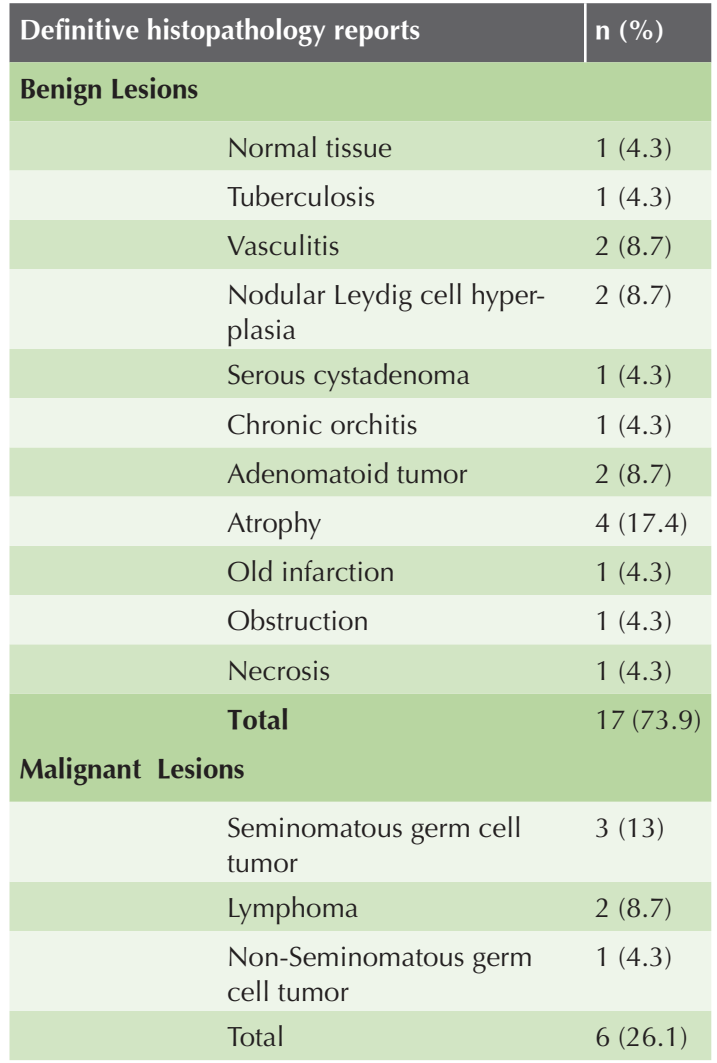

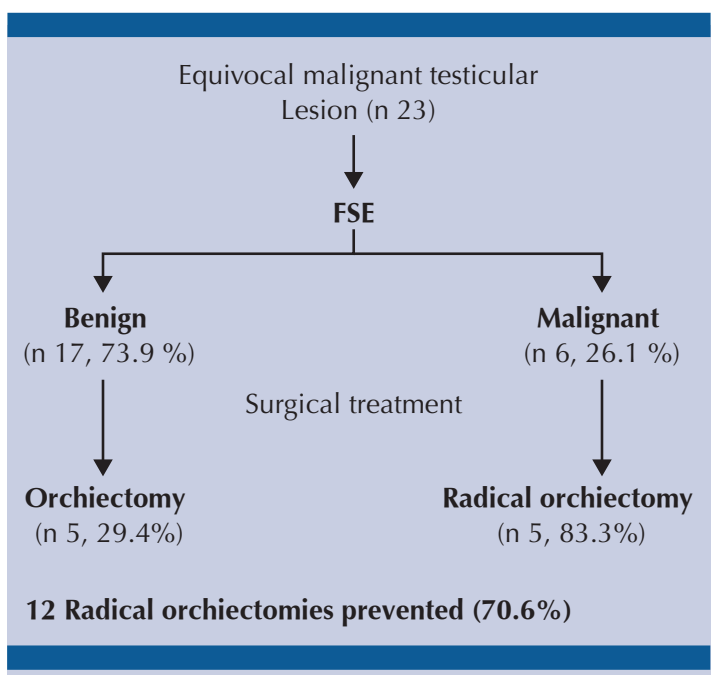

Figure 1. Surgical treatment of equivocal malignant testicular masses.

Regarding the early complications of FSE, 3 patients $(12.5 \%)$ had grade I complications (two hematomas and one seroma). No patients presented with grade II complications, or higher. In the long term, 2 patients presented with testicular atrophy.

There were no malignant formations during follow-up (median: 9 months) in any of the patients that did not undergo radical orchiectomy as a result of the benign FSE report.

\section{FSE diagnostic value}

There were no diagnostic changes made in relation to the FSE reports and the definitive pathology reports. Table 4 summarizes the sensitivity, specificity, and predictive values of FSE for malignant lesions. The degree of concordance between the FSE reports and the definitive malignant reports was statistically significant $(\kappa=1.0, p<0.05)$.

\section{DISCUSSION}

Radical orchiectomy is the standard treatment for a suspicious malignant lesion, but testis-sparing 
Table 4. Sensitivity, specificity and predictive values of FSE of Equivocal Malignant Testicular Masses.

\begin{tabular}{l|c|c|c|c|c|c|}
\multirow{2}{*}{ FSE } & \multicolumn{2}{|c|}{ Definitive } & $\begin{array}{c}\text { Sensi- } \\
\text { tivity } \\
(\%)\end{array}$ & $\begin{array}{c}\text { Speci- } \\
\text { ficity } \\
(\%)\end{array}$ & $\begin{array}{c}\text { PPV } \\
(\%)\end{array}$ & $\begin{array}{c}\text { NPV } \\
(\%)\end{array}$ \\
\cline { 2 - 8 } & Malignant & Benign & & & & \\
Malignant & 6 & 0 & 100 & 100 & 100 & 100 \\
Benign & 0 & 17 & & & &
\end{tabular}

PPV, positive predictive value. NPV, negative predictive value.

surgery (TSS) can be an alternative approach for benign lesions. FSE could help identify those patients suitable for TSS. In our study, FSE demonstrated high sensitivity and specificity. Our findings were similar to those reported in previous series [1, 4]. In 2006, Connolly et al. described a PPV, NPV, sensitivity, and specificity of 94.2, 92.6, 96.1, and $89.3 \%$, respectively[6]. Table 5 summarizes the testicular FSE diagnostic accuracy found in different studies. Complete concordance between the FSE and definitive pathology reports for malignant lesions was found in the present analysis, similar to that of other studies with reported kappa values of 0.76 to $1[3,7]$.

In our study, $26.1 \%$ of the EMTMs were malignant, whereas other authors report frequencies of $0 \%$ to $89.5 \%[2,6,12,13]$. No false negative results were seen in the present study. In 2015, Silverio et al. described a 3.5\% tumor identification failure rate; of 6 false negatives, 3 were due to an inadequate sample and the other 3 were most likely associated with small tumor size, frozen section artifacts, or pathologist experience [11]. Even though our institution does not have a specialized uropathologist, FSE reliability was high, lending support to its regular use at other centers in similar situations.

Radical orchiectomy was not performed on most of our patients with benign pathology $(70.6 \%)$, which was similar to the results of other series, in which 74.5 to $88.2 \%$ of patients did not require radical surgery because of benign results $[10,11]$. Nevertheless, orchiectomy can be necessary in benign lesions when there are conditions of total testicular necrosis, testicular atrophy, questionable viability, extended lesions with significant testicular destruction, or nonfunctional testis.

We found no significant associations between clinical or ultrasound characteristics and a malignant FSE report. In other series, malignant lesions were associated with greater tumor size $[3,6,10]$. The ultrasound finding of a low-volume testicular lesion can suggest the difference between benign and malignant lesions, but diagnostic accuracy is low $[14,15]$.

Table 5. FSE Diagnostic accuracy results from different studies evaluating testicular masses..

\begin{tabular}{|l|c|c|c|c|c|c|}
\hline Authors, Publication year & $\mathbf{N}$ & Benign / Malignant (\%) & Sn & Sp & PPV & NPV \\
\hline Elert et al [2], 2002 & 354 & $10.5 / 89.5$ & 100 & 100 & 100 & 100 \\
\hline Leroy et al[8], 2003 & 15 & $73.3 / 26.6$ & 100 & 100 & 100 & 100 \\
\hline Connolly et al[9], 2006 & 80 & $35 / 65$ & 96.1 & 89.3 & 94.2 & 92.6 \\
\hline Subik et al[10], 2012 & 45 & $57.7 / 42.2$ & 100 & 95 & 96 & 100 \\
\hline Silverio et al[11], 2015* & 159 & $23.8 / 76.1$ & 95 & 100 & 95 & 100 \\
\hline Matei et al[3], 2017 & 144 & $43.1 / 52.1$ & 93 & 98 & 99 & 91 \\
\hline Current study, 2018 & 23 & $73.9 / 26.1$ & 100 & 100 & 100 & 100
\end{tabular}

Sn, Sensitivity; Sp, Specificity; PPV, Positive Predictive Value; NPV, Negative Predictive Value.

*Sn, Sp, PPV, NPV are calculated including 11 paratesticular lesions. 
The complication rate in our study was $12.5 \%$ and all were Clavien-Dindo grade I complications. To the best of our knowledge, the present study is the first to use the Clavien-Dindo classification for complications of testicular FSE. A few studies have reported complication rates in patients with benign pathology that vary from no complications [6] up to $8.1 \%$ for testicular atrophy and hematomas and $2.7 \%$ for orchitis/ epididymitis [2].

No malignant neoformations were observed during follow-up in our patients that had a benign FSE report. Similar findings are reported in other studies, in which no malignancy development was seen at mean follow-up times of 77.8 months and 105 months $[2,6]$.

Limitations of our study include its retrospective design, data taken from a single center, and the small number of patients. However, FSE in EMTMs appears to be a useful tool for clinical practice, with excellent diagnostic accuracy and a low probability of complications. FSE can potentially prevent unnecessary radical orchiectomies in selected patients.

\section{CONCLUSION}

Testicular frozen section examination is a reliable technique in the management of equivocal malignant mass management and is associated with low-grade complications.

\section{Conflicts of interest}

The authors declare that there is no conflict of interest.

\section{Financial}

No financial support was received in relation to this study/article.

\section{REFERENCES}

1. Carmignani, L., et al., High incidence of benign testicular neoplasms diagnosed by ultrasound. J Urol, 2003. 170(5): p. 1783-6.

2. Elert, A., et al., Accuracy of frozen section examination of testicular tumors of uncertain origin. Eur Urol, 2002. 41(3): p. 290-3.

3. Matei, D.V., et al., Reliability of Frozen Section Examination in a Large Cohort of Testicular Masses: What Did We Learn? Clin Genitourin Cancer, 2017.

4. Tokuc, R., et al., Accuracy of frozen section examination of testicular tumors. Urology, 1992. 40(6): p. 512-6.

5. Bossuyt, P.M., et al., STARD 2015: an updated list of essential items for reporting diagnostic accuracy studies. BMJ, 2015. 351: p. h5527.

6. Connolly, S.S., et al., Carefully selected intratesticular lesions can be safely managed with serial ultrasonography. BJU Int, 2006. 98(5): p. 1005-7; discussion 1007.

7. Ates, F., et al., Testis-Sparing Surgery in Small Testicular Masses Not Suspected to Be Malignant. Clin Genitourin Cancer, 2016. 14(1): p. e49-53.

8. Leroy, X., et al., Value of frozen section examination for the management of nonpalpable incidental testicular tumors. Eur Urol, 2003. 44(4): p. 458-60.

9. Connolly, S.S., et al., Value of frozen section analysis with suspected testicular malignancy. Urology, 2006. 67(1): p. $162-5$.

10. Subik, M.K., et al., Frozen section assessment in testicular and paratesticular lesions suspicious for malignancy: its role in preventing unnecessary orchiectomy. Hum Pathol, 2012. 43(9): p. 1514-9.

11. Silverio, P.C., et al., Fourteen-year experience with the intraoperative frozen section examination of testicular lesion in a tertiary university center. Ann Diagn Pathol, 2015. 19(3): p. 99-102.

12. Colpi, G.M., et al., Testicular-sparing microsurgery for suspected testicular masses. BJU Int, 2005. 96(1): p. 67-9.

13. Passman, C., et al., Testicular lesions other than germ cell tumours: feasibility of testis-sparing surgery. BJU Int, 2009. 103(4): p. 488-91.

14. Rocher, L., et al., Incidentally detected non-palpable testicular tumours in adults at scrotal ultrasound: impact of radiological findings on management Radiologic review and recommendations of the ESUR scrotal imaging subcommittee. Eur Radiol, 2016. 26(7): p. 2268-78.

15. Bhatt, S., et al., Imaging of non-neoplastic intratesticular masses. Diagn Interv Radiol, 2011. 17(1): p. 52-63. 